\title{
Correction to: Agarotetrol: a source compound for low molecular weight aromatic compounds from agarwood heating
}

\author{
Sakura Takamatsu ${ }^{1} \cdot{\text { Michiho } \text { Ito }^{1}}^{1}$
}

Published online: 24 April 2019

(c) The Japanese Society of Pharmacognosy 2019

\section{Correction to: \\ Journal of Natural Medicines (2018) 72:537-541 \\ https://doi.org/10.1007/s11418-018-1185-y}

In the original publication of the article, under the paragraphs "Collection of volatile compound" and "Analysis of essential oil and hydrosol" holding time for the end of GC and GC-MS programs at $180^{\circ} \mathrm{C}$ was incorrectly published as "10 min". The correct time limit is " $30 \mathrm{~min}$ ".

Publisher's Note Springer Nature remains neutral with regard to jurisdictional claims in published maps and institutional affiliations.

The original article can be found online at https://doi.org/10.1007/ s11418-018-1185-y.

Michiho Ito

michihoi@pharm.kyoto-u.ac.jp

1 Graduate School of Pharmaceutical Sciences, Kyoto

University, 46-29 Yoshidashimoadachi-cho, Sakyo-ku,

Kyoto 606-8501, Japan 